\title{
Evaluating a commercial PCR assay against bacterial culture for diagnosing Streptococcus uberis and Staphylococcus aureus throughout lactation
}

\author{
N. M. Steele, ${ }^{*} \dagger^{1}$ J. H. Williamson, ${ }^{*}$ R. Thresher, $\ddagger$ R. A. Laven, $\S$ and J. E. Hillerton\# \\ *DairyNZ, Private Bag 3221, Hamilton, 3240, New Zealand \\ †Department of Dairy Sciences, Virginia Polytechnic Institute and State University, Blacksburg 24061 \\ fLivestock Improvement Corporation, Riverlea, Hamilton, 3216, New Zealand \\ §Institute of Veterinary, Animal and Biomedical Sciences, Massey University, Palmerston North, 4471, New Zealand \\ \#Drumlanrig, Cambridge, New Zealand 3496
}

\section{ABSTRACT}

The performance of a commercial, real-time PCR assay was compared with traditional bacterial culture for the identification of Streptococcus uberis and Staphylococcus aureus in bovine milk collected at different stages of lactation. Initial validation tests using fresh and frozen quarter milk samples identified factors that affected the success of the PCR. Therefore, the standard protocol was adjusted for samples collected at the first milking postpartum (colostrum) and from clinical mastitis cases. The adjustment involved PCR testing both undiluted and diluted ( 1 in 10 with sterile water) DNA extracts. The performance comparison between culture and the PCR assay used milk samples collected aseptically from individual quarters of mixed-age spring-calving dairy cows, during early, mid, and late lactation. Bacterial culture results were used to select a subset of samples for PCR testing $(\mathrm{n}=315)$ that represented quarters with a current or prior Strep. uberis or Staph. aureus infection. Compared with culture, PCR had a sensitivity of $86.8 \%$ and specificity of $87.7 \%$ for detecting Strep. uberis (kappa $=0.74$ ) and $96.4 \%$ and $99.7 \%$, respectively, for detecting Staph. aureus (kappa $=0.96)$. The dilution of DNA extracts for colostrum and clinical samples increased the relative sensitivity from $79.2 \%$ to $86.8 \%$ for Strep. uberis detection and from $92.9 \%$ to $96.4 \%$ for Staph. aureus, presumably through diluting unidentified PCR inhibitors. The sensitivity for detecting Strep. uberis using PCR, relative to culture, was similar throughout lactation (85-89\%), whereas relative specificity was lowest immediately postcalving (64\%) but improved in mid and late lactation $(98 \%)$. Specificity estimates for samples collected in early lactation can be optimized by reducing the cutoff cycle threshold $(\mathrm{Ct})$ value from the recommended value of 37 to 34 . Although using this value improved

Received July 18, 2016.

Accepted December 29, 2016

${ }^{1}$ Corresponding author: Nicole.Steele@dairynz.co.nz specificity (77\%), it reduced test sensitivity (77\%). The PCR assay lacked agreement with culture in early lactation, specifically for diagnosing Strep. uberis. Thus, PCR should not be used as the only tool for diagnosing mastitis in early lactation.

Key words: mastitis pathogen, polymerase chain reaction, colostrum

\section{INTRODUCTION}

Worldwide, mastitis is the most costly infectious disease of dairy cattle because of its high incidence in all dairy systems and its effects on animal welfare, milk quality, and milk yield (Barkema et al., 2009). More than 130 different bacterial species have been reported to cause mastitis (Watts, 1988). Nevertheless, 10 bacterial species or groups of species commonly account for more than $95 \%$ of mastitis infections (Koivula et al., 2007). Identifying the species of bacteria causing mastitis is an important part of mastitis control, assisting in herd management decisions such as analysis of risk, selection of lactating and dry cow antibiotic therapy, and culling. Between 65 and $85 \%$ of antimicrobial use in dairy farming can be attributed to mastitis (Pol and Ruegg, 2007). Regulations controlling antibiotic use are being tightened; therefore, enhanced diagnostic tests will be required for more effective and prudent use of antibiotics.

The accepted gold standard test for laboratory-based identification of mastitis pathogens is bacterial culture (Hogan et al., 1999). New molecular technologies, such as PCR, are being applied in mastitis pathogen identification (Gillespie and Oliver, 2005; Koskinen et al., 2009). Compared with culture, the main advantages of PCR include faster diagnosis, objective bacterial identification, and the ability to detect lower concentrations of bacterial DNA through the amplification of specifically targeted DNA sequences (Koskinen et al., 2009; Taponen et al., 2009). PCR has also been shown to detect bacteria in clinical samples that failed to grow in conventional culture (Taponen et al., 2009). However, 
some uncertainty exists around the use of PCR in mastitis diagnosis. The range of bacteria detected by PCR is usually more limited than culture because PCR only detects the bacteria that are targeted by the primers included in the assay. In addition, PCR detects bacterial DNA, so, unlike culture, it is not dependent on the viability of bacteria (Cressier and Bissonnette, 2011), which creates difficulty when interpreting whether a positive PCR result is significant. Finally, samples from cases of clinical mastitis and the colostrum period have different physical and biochemical characteristics compared with normal milk. Immune components can affect the efficiency of DNA extraction and subsequently the success of PCR (Cremonesi et al., 2006; Cressier and Bissonnette, 2011).

Most mastitis-related studies have focused on the use of PCR to identify contagious pathogens such as Streptococcus agalactiae, Mycoplasma bovis, and Staphylococcus aureus from clinical cases, high SCC quarter and composite milk, and bulk tank samples (Koskinen et al., 2010; Mahmmod et al., 2013). Few studies have evaluated PCR for the detection of Streptococcus uberis (Gillespie and Oliver, 2005; Koskinen et al., 2010); however, this pathogen is a frequent cause of intramammary infection in many herds, particularly in early lactation and in pasture farming systems (Compton et al., 2007). The objectives of this study were to validate the PathoProof Complete 12 Mastitis PCR assay (ThermoScientific, Vantaa, Finland) for use in a high incidence Strep. uberis system and to assess the comparative performance of the PCR assay with conventional microbiological culture methods for detection of Strep. uberis and Staph. aureus in quarter milk samples collected after calving and later in lactation.

\section{MATERIALS AND METHODS}

\section{Sample Collection and Handling}

Initial validation of the PCR assay used both freshly collected $(\mathrm{n}=8)$ and frozen $(\mathrm{n}=20)$ milk samples. Fresh samples were collected aseptically from individual quarters of cows on a DairyNZ research farm in Waikato, New Zealand, in early lactation, and kept at $4^{\circ} \mathrm{C}$ for $2 \mathrm{~d}$ until PCR testing. Frozen samples were collected aseptically from quarters of cows on local commercial herds during early, peak, or late lactation and had been stored at $-20^{\circ} \mathrm{C}$ for 1 to $2 \mathrm{yr}$. Samples were selected for the validation study based on bacterial culture results, consisting of Strep. uberis $(\mathrm{n}=14)$; Staph. aureus $(\mathrm{n}=$ 8); streptococci other than Strep. uberis $(\mathrm{n}=2)$; CNS $(\mathrm{n}=1)$; and no pathogen isolated $(\mathrm{n}=3)$.

For the test comparison study, milk samples ( $\mathrm{n}=$ 6,818 ) were collected throughout lactation from a pop- ulation of 480 spring-calving mixed-age dairy cows on 2 research farms in Waikato, New Zealand. All sampling was approved by the Ruakura Animal Ethics Committee (no. 12948). In early lactation, all functional quarters of 480 cows (2 herds) were sampled at the first (M1) and tenth (M10) milking after calving. A quarter that was positive in culture for any pathogen at M1 or M10 was sampled again 30 to $37 \mathrm{~d}$ into lactation (D30), forming a set of 3 samples from each infected quarter in early lactation. In mid lactation, approximately 100 DIM, cows on one of the research farms $(\mathrm{n}=330)$ were sampled (R1), and culture-positive quarters were resampled $7 \mathrm{~d}$ later $(\mathbf{R} \mathbf{1}+\mathbf{7})$. In late lactation, approximately 200 DIM, the same 330 cows were sampled again (R2), and any quarter that was positive in culture at the late-lactation sample point was resampled $7 \mathrm{~d}$ later $(\mathbf{R 2}+\mathbf{7})$. This process formed 2 independent sets, both consisting of 2 samples to represent an infected quarter in mid and late lactation. Additionally, any quarter diagnosed with clinical mastitis (CM) was sampled. After bacterial culture, samples were stored at $-20^{\circ} \mathrm{C}$ for an average of $200 \mathrm{~d}$ ( (ange $=60-270 \mathrm{~d}$ ) until PCR testing. The length of storage reflects the time taken to import and initially validate the assay.

\section{Microbiological Methods}

Milk samples were collected from individual quarters using aseptic technique. Standard bacterial culture was completed on all samples according to National Mastitis Council (NMC) guidelines (Hogan et al., 1999) within $48 \mathrm{~h}$ of fresh sample collection. For culture, 10 $\mu \mathrm{L}$ of milk was streaked on one quadrant of an esculin blood agar plate (Fort Richard Laboratories Ltd., Otahuhu, Auckland, New Zealand). Plates were incubated aerobically at $37^{\circ} \mathrm{C}$ for $48 \mathrm{~h}$. A quarter was identified as infected when at least 1 colony of a major bacterial species was isolated and when at least 3 colonies of a minor mastitis pathogen were isolated (Dohoo et al., 2011b). A sample was contaminated if 3 or more dissimilar colony types were present in culture (Hogan et al., 1999). The contamination rate across all samples collected in the field study was $1.7 \%$.

Before PCR testing, samples to be used in the test comparison were thawed overnight at $4^{\circ} \mathrm{C}$, and standard culture was repeated using $10 \mu \mathrm{L}$. Additionally, colony counts were completed in triplicate using 100 $\mu \mathrm{L}$ of milk spread on a whole esculin blood agar plate and the 3 counts were averaged. Any quarter positive for a pathogen in at least 1 of the 3 bacteriological tests (fresh culture, frozen culture, or plate colony count) was considered infected [parallel interpretation; Dohoo et al. (2009)]. Additional biochemical testing using API 20 Strep strips (bioMérieux, Lyon, France) was con- 
ducted for samples that required confirmation of Strep. uberis identification after PCR testing.

\section{PCR Assay Protocol Validation}

The real-time PCR assay (PathoProof Mastitis Complete 12) is capable of detecting 11 mastitis-causing bacterial species or species groups and 1 resistance gene in 4 separate multiplex reactions; each reaction includes 3 targets and a control. Two reactions were excluded because the targeted pathogens were not relevant to the study. Therefore, the assay could identify 6 bacterial targets: Staph. aureus, Enterococcus spp. (including Enterococcus faecalis and Enterococcus faecium), Corynebacterium bovis, Staphylococcus spp. (including Staph. aureus and CNS), Strep. agalactiae, and Strep. uberis.

Bacteriological status was confirmed using standard bacterial culture (Hogan et al., 1999) and was repeated for stored samples immediately before PCR testing. Adjustments were made to the PCR assay protocol to reduce the incidence of reaction failure and false-positive results. This process included replacing the supplied, interconnected 2-mL collection tubes for manual DNA extraction with separate 1.5-mL sterile Eppendorf tubes to reduce the potential for cross-contamination using the supplied tubes. Additionally, a dilution step was added for all M1 and CM samples. The DNA extract from each of these M1 and CM samples was run in PCR as a normal undiluted replicate (Rep1), as per manufacturer's recommendations, and as a 1-in-10 diluted replicate (Rep2) in sterile water.

\section{Real-Time PCR Assay}

Milk samples were prepared manually for DNA extraction. For the extraction of DNA, enzymatic lysis and centrifugation steps isolated bacterial cells from $400 \mu \mathrm{L}$ of milk. DNA was purified using the magnetic bead-based method and elution was automated using the Kingfisher 96 (Thermo Electron, Vantaa, Finland). Each PCR run was prepared in a 96-well plate, with each well combining $5 \mu \mathrm{L}$ of extracted sample DNA, 10 $\mu \mathrm{L}$ of Master Mix, $5 \mu \mathrm{L}$ of the reaction specific Primer Mix, and an internal amplification control (IAC). Real-time PCR was run on the 7500 Fast Real Time PCR system (Applied Biosystems, Foster City, CA). The thermal cycling protocol was as follows: $10 \mathrm{~min}$ at $95^{\circ} \mathrm{C}$, then 40 cycles of $5 \mathrm{~s}$ at $95^{\circ} \mathrm{C}$ and $60 \mathrm{~s}$ at $60^{\circ} \mathrm{C}$, followed by $5 \mathrm{~s}$ at $25^{\circ} \mathrm{C}$. Samples were considered positive or negative for a bacterial target based on a cycle threshold (Ct) value of 37, as described by Koskinen et al. (2009). Negative controls were included to rule out cross-contamination. Before scoring any reaction as positive, acceptable PCR conditions were confirmed by verifying that the $\mathrm{Ct}$ values and shape of the amplification curves for the IAC were acceptable (Taponen et al., 2009). If the IAC was not acceptable, the result was classified as "reaction failure."

\section{Performance Comparison of the PCR Assay Against Bacterial Culture}

Samples for PCR analysis were from the full population of quarter samples collected in the field study (Table 1), where the prevalence of Strep. uberis and Staph. aureus was 2.7 and $0.5 \%$, respectively. Sample size calculation was based on historical data, in which approximately $5 \%$ of all samples collected were expected to be positive in culture for Strep. uberis or Staph. aureus $(\mathrm{n}=340)$. A total of 220 samples were positive in culture for these pathogens and suitable for the test comparison, which exceeded the minimum requirement of 196 samples for $80 \%$ power of test.

Samples were selected for the comparison based on infection with either Strep. uberis or Staph. aureus, as determined by culture. To represent changes in infection in individual quarters, complete sets of either 2 or 3 consecutive samples at a separate stage of lactation (early, mid, or late lactation) were selected, with at least one sample in the set being culture positive for Strep. uberis or Staph. aureus. A proportion of culturenegative samples from quarters that were healthy in the previous lactation were also included for each stage of lactation. Individual quarter samples were used as the unit for comparison. The gold standard definition for a positive sample was a culture-positive result for the pathogen of interest in at least 1 of the 3 bacteriological tests (fresh culture, frozen culture, or plate colony count). A sample that was positive for one pathogen but negative for the other pathogen of interest was considered as a true positive for the former pathogen and a true negative for the latter pathogen.

A total of 343 quarter milk samples from 108 cows were analyzed by both bacterial culture and the PCR assay. Samples collected from quarters that had been treated with antibiotics within $21 \mathrm{~d}$ of the scheduled sample collection were excluded from analyses $(\mathrm{n}=$ 28), leaving 315 samples for the comparison of the PCR test with bacterial culture (Table 2).

All samples were run in duplicate in PCR, with the exception of M1 and CM samples because of the dilution step that was found to be necessary in the validation study. PCR Ct values were averaged if both duplicates were $<37$. If one duplicate was $\geq 37$ and the other was $<37$, the latter value was used. If both duplicates were $\geq 37$, the sample was considered to be negative (Koski- 
Table 1. Number (\% in parentheses) of culture-negative samples (OO) and culture-positive samples in which the predominant pathogen identified was Streptococcus uberis (SU), Staphylococcus aureus (SA), CNS, Escherichia coli (EC), other pathogens, or contaminated (CS) in culture, for all samples collected throughout lactation

\begin{tabular}{lccrrrrrr}
\hline \multicolumn{7}{c}{ Sampling } & \multicolumn{7}{c}{ Culture result } & \\
\cline { 2 - 5 } point $^{1}$ & OO & SU & SA & CNS & EC & Other $^{2}$ & CS & Total \\
\hline M1 & $1,689(88)$ & $78(4)$ & 8 & 53 & 4 & 27 & 51 & 1,910 \\
M10 & $1,779(93)$ & $34(2)$ & 5 & 34 & 5 & 26 & 29 & 1,912 \\
D30 & $168(80)$ & $7(3)$ & 5 & 26 & 1 & 12 & 0 & 219 \\
CM & $5(9)$ & $37(65)$ & 0 & 4 & 1 & 8 & 2 & 57 \\
R1 & $1,225(94)$ & $6(<1)$ & 3 & 37 & 0 & 5 & 23 & 1,299 \\
R1+7 & $13(27)$ & $5(10)$ & 2 & 28 & 0 & 0 & 0 & 48 \\
R2 & $1,208(93)$ & $11(<1)$ & 5 & 51 & 0 & 14 & 10 & 1,299 \\
R2+7 & $13(18)$ & $9(12)$ & 5 & 41 & 0 & 6 & 0 & 74 \\
Total & 6,100 & 187 & 33 & 274 & 11 & 98 & 115 & 6,818 \\
\hline
\end{tabular}

${ }^{1} \mathrm{M} 1$ = first milking; M10 = 10th milking; D30 = 30 DIM; CM = clinical mastitis; R1 = mid lactation; R1+7 $=7 \mathrm{~d}$ after R1 sample; $\mathrm{R} 2=$ late lactation; $\mathrm{R} 2+7=7 \mathrm{~d}$ after $\mathrm{R} 2$ sample.

${ }^{2}$ Other includes yeasts, Corynebacterium bovis, streptococci (other than Strep. agalactiae and Strep. uberis),

Trueperella spp., Enterococcus spp., and Serratia spp.

nen et al., 2009). For M1 and CM samples, the Ct value for the undiluted Rep1 was expected to be $\sim 3.3$ cycles less than the Ct value for the diluted 1-in-10 Rep2 (Koskinen et al., 2009); if this expectation was met, Rep1 was used for analysis. If Rep1 $\geq$ Rep2, Rep2 was used for analysis because the PCR was likely inhibited for the undiluted sample. Rep2 was also used if Rep1 was missing due to unacceptable IAC conditions.

\section{Statistical Analysis}

All statistical analyses were performed using Excel and Minitab (version 16.2.3, Minitab Inc., State College, PA). Relative sensitivity (Se) was defined as the proportion of "true" positive results (according to culture) that were correctly identified by PCR and relative specificity ( $\mathbf{S p}$ ) as the proportion of "true" negative results correctly identified by PCR. Sensitivity and Sp were calculated separately for Strep. uberis and Staph. aureus, where quarter samples positive for only one pathogen were considered culture negative for the other pathogen. The kappa statistic $(\kappa)$ was calculated to determine the agreement between culture and PCR beyond that expected by chance (Cohen, 1960). Coefficients of variation (CV) and repeatability were estimated for samples that had $2 \mathrm{Ct}$ values $(<40)$. Samples were grouped in accordance with the semiquantitative reporting by the manufacturer, based on $\mathrm{Ct}$ value $<30(++$ or +++$)$ or $\geq 30(+)$. The $\mathrm{CV}$ is the standard deviation for repeatability divided by the mean. Repeatability is the standard deviation multiplied by 2.8 (ASTM International, 2014). Mid and late

Table 2. Number (\% in parentheses) of culture-negative samples (OO) and culture-positive samples in which the predominant pathogen identified was Streptococcus uberis (SU), Staphylococcus aureus (SA), CNS, or other pathogens, for samples included in the performance comparison between culture and PCR at the different sampling points

\begin{tabular}{|c|c|c|c|c|c|c|}
\hline \multirow{2}{*}{$\begin{array}{l}\text { Sampling } \\
\text { point }^{1}\end{array}$} & \multicolumn{5}{|c|}{ Culture result } & \multirow[b]{2}{*}{ Total } \\
\hline & $\mathrm{OO}$ & SU & SA & CNS & Other $^{2}$ & \\
\hline M1 & $7(8)$ & $72(83)$ & $4(5)$ & 2 & 2 & 87 \\
\hline M10 & $33(45)$ & $34(47)$ & $4(5)$ & 2 & 0 & 73 \\
\hline D30 & $69(84)$ & $7(9)$ & $5(6)$ & 1 & 0 & 82 \\
\hline $\mathrm{CM}$ & $0(0)$ & $2(100)$ & $0(0)$ & 0 & 0 & 2 \\
\hline $\mathrm{R} 1$ & $13(59)$ & $5(23)$ & $3(14)$ & 1 & 0 & 22 \\
\hline $\mathrm{R} 1+7$ & $1(13)$ & $5(63)$ & $2(25)$ & 0 & 0 & 8 \\
\hline $\mathrm{R} 2$ & $9(35)$ & $10(38)$ & $5(19)$ & 1 & 1 & 26 \\
\hline $\mathrm{R} 2+7$ & $1(7)$ & $8(53)$ & $5(33)$ & 0 & 1 & 15 \\
\hline Total & 133 & 143 & 28 & 7 & 4 & 315 \\
\hline
\end{tabular}


lactation samples were combined for analysis because of low sample numbers.

\section{RESULTS}

\section{PCR Assay Validation Study}

The PCR assay was validated using stored $(\mathrm{n}=20)$ and fresh milk samples $(\mathrm{n}=8)$. The first PCR run using the supplied, interconnected tubes provided falsepositive PCR results for 6 samples for Strep. uberis and for 3 samples for Staph. aureus out of 20 samples. Cross-contamination errors were suspected during the DNA extraction phase because of the close proximity of adjacent sample tubes. The DNA extraction was repeated for these samples using separate 1.5-mL Eppendorf tubes. No false positives were generated, and the relative specificity increased to $100 \%$ for both pathogens. The Eppendorf tubes were used for the remainder of the study.

Of the 28 samples tested, 3 samples had unacceptable IAC Ct values and amplification curves, indicating reaction failure. Common to all failures was that they were thick colostrum or clotted clinical mastitic milk, though not all samples with these characteristics failed to amplify in PCR. When PCR was repeated using a 1-in-10 dilution of the DNA extract in sterile water, acceptable IAC characteristics were achieved in all samples that had failed previously. For the test com- parison, the DNA extract from all first milking samples $(\mathrm{n}=87)$ and cases of clinical mastitis were run in PCR as both undiluted and 1-in-10 diluted replicates.

\section{Performance Comparison of the PCR Assay Against Bacterial Culture}

Out of 315 samples, bacterial culture identified Strep. uberis as the predominant pathogen in 143 samples $(46 \%)$ and Staph. aureus in 28 samples (9\%); 133 samples $(42 \%)$ had no growth (Table 2). The remaining culture results were CNS $(\mathrm{n}=7)$ and one each of Escherichia coli, streptococci (other than Strep. agalactiae, Strep. dysgalactiae, and Strep. uberis), yeast, and enterococci.

The majority of samples identified in culture as being positive for Staph. aureus were correctly diagnosed by PCR $(99.4 \%)$, with one false negative at M1 and one false positive at D30. Relative to culture, the PCR test performance was $\mathrm{Se}=96.4 \%$ and $\mathrm{Sp}=99.7 \%$ for detecting Staph. aureus across all stages of lactation (Table 3). The agreement between culture and PCR for Staph. aureus detection was high; $\kappa=0.961$. The dilution step enabled the identification of one additional Staph. aureus-positive sample that would have otherwise been missed, increasing the sensitivity from 92.9 to $96.4 \%$.

For the detection of Strep. uberis, both culture and PCR returned a positive result in 125 samples, and a

Table 3. Cross-classification of bacterial culture (BC) and PCR results for Streptococcus uberis and Staphylococcus aureus detection for all samples (including clinical mastitis samples; $n=2$ ), and at each sampling point, ${ }^{1}$ and the relative sensitivity (Se) and specificity (Sp) of the PCR test and associated kappa statistics

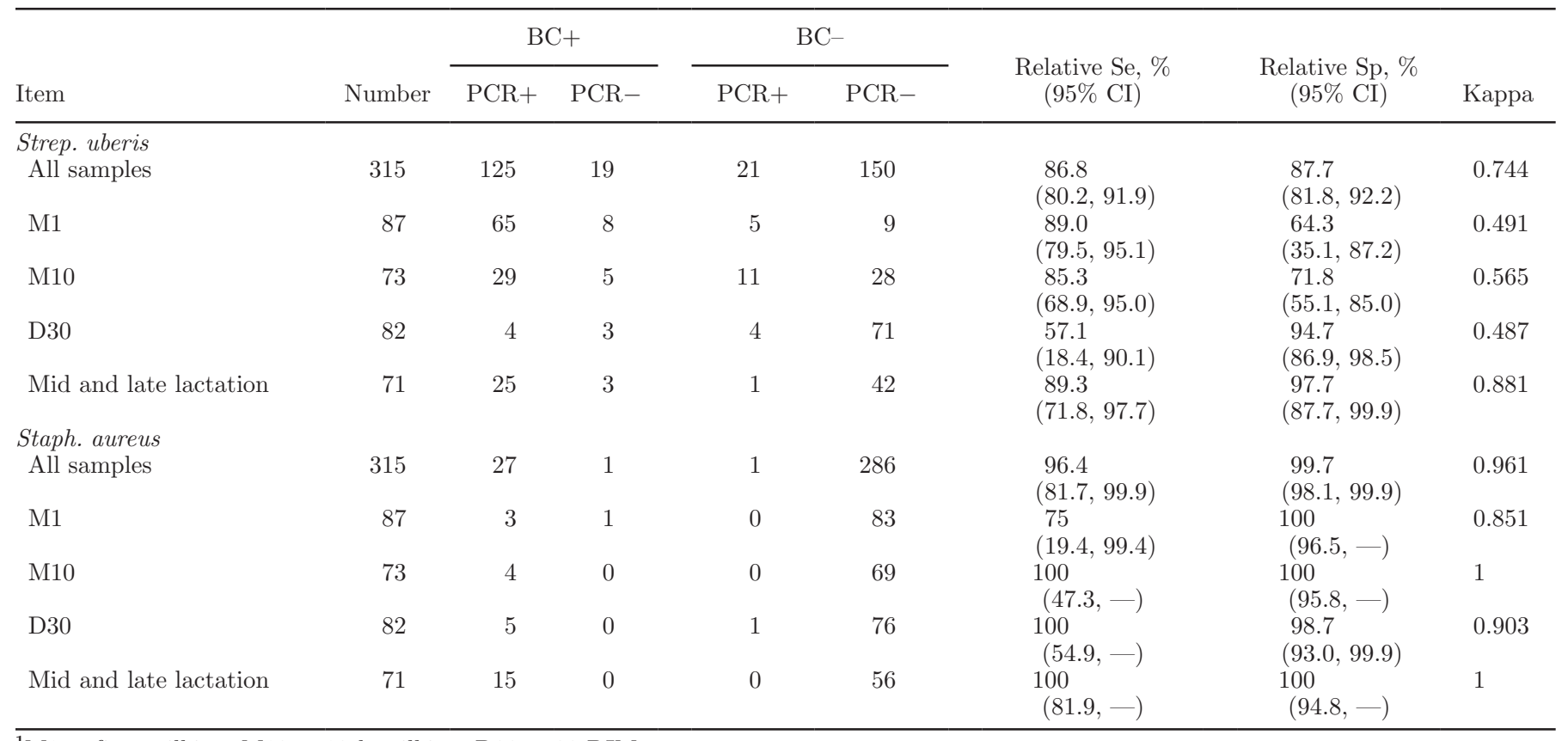

${ }^{1} \mathrm{M} 1=$ first milking; M10 = 10th milking; D30 = 30 DIM. 
negative result in 150 samples (Table 3). Forty conflicting results were found between culture and PCR (12.7\%); 19 samples were positive in culture but negative using PCR (PCR false negative), and 21 samples were negative in culture but positive using PCR (PCR false positive). Strep testing by API (bioMérieux) was completed on 12 of the PCR false negatives, confirming Strep. uberis in these samples. Thus, for Strep. uberis detection, the PCR test had a relative sensitivity of $86.8 \%$ and relative specificity of $87.7 \%$, using the parallel interpretation of the 3 bacteriological tests. In comparison, interpretation in series in which all 3 bacteriological tests had to be positive for the sample to be gold standard positive had only slight changes in relative sensitivity (91.1\%) and specificity (82.3\%) of the PCR test (data not shown). The $\kappa$ agreement between methods for Strep. uberis detection was 0.744.

Sensitivity was similar for all sampling times (85$89 \%$ ), with the exception of D30 (Se $=57 \%)$ because of insufficient samples to determine sensitivity with accuracy. The dilution step for all first milking (M1) and CM samples resulted in an additional 11 Strep. uberis culture-positive samples being detected in PCR, improving the overall test sensitivity from 79.2 to $86.8 \%$. Large differences were observed in the specificity of the PCR test at the different stages of lactation, ranging from $64 \%$ for M1 samples to $98 \%$ for mid and late lactation. Thirty-six of the 40 conflicting results were samples collected in early lactation (M1, M10, or D30).

\section{Sensitivity and Specificity Optimization for Strep. uberis}

The cutoff $\mathrm{Ct}$ value used for determining positive and negative results was 37 , as recommended by the manufacturer. Applying a Ct cutoff of 32 increased the specificity, but reduced the sensitivity for detecting Strep. uberis (Figure 1). As the cutoff Ct value increased from 32 to 39 , the specificity declined from 92 to $50 \%$ for M1 samples and from 88 to $67 \%$ for M10 samples. Sensitivity was highest at a cutoff of 37 for M1 samples (89\%) and Ct 39 for M10 samples (91\%). Increasing the Ct cutoff from 32 to 37 did not change the specificity of the PCR test for mid- and late-lactation samples; however, the sensitivity increased from 71 to $89 \%$. No benefit was found from using a Ct cutoff of 39 for mid and late lactation samples. D30 samples were excluded from this analysis because of the limited number of Strep. uberis-positive samples.

\section{Intra-Assay Repeatability}

Coefficients of variation up to $3 \%$ were considered acceptable. For duplicates that had 2 valid PCR results, less variation and hence lower CV and repeatability measures were observed for samples with $\mathrm{Ct}$ values $<30$, compared with those with $\mathrm{Ct}$ values $\geq 30$. This effect was apparent for both Strep. uberis and Staph. aureus identification by PCR (Table 4).

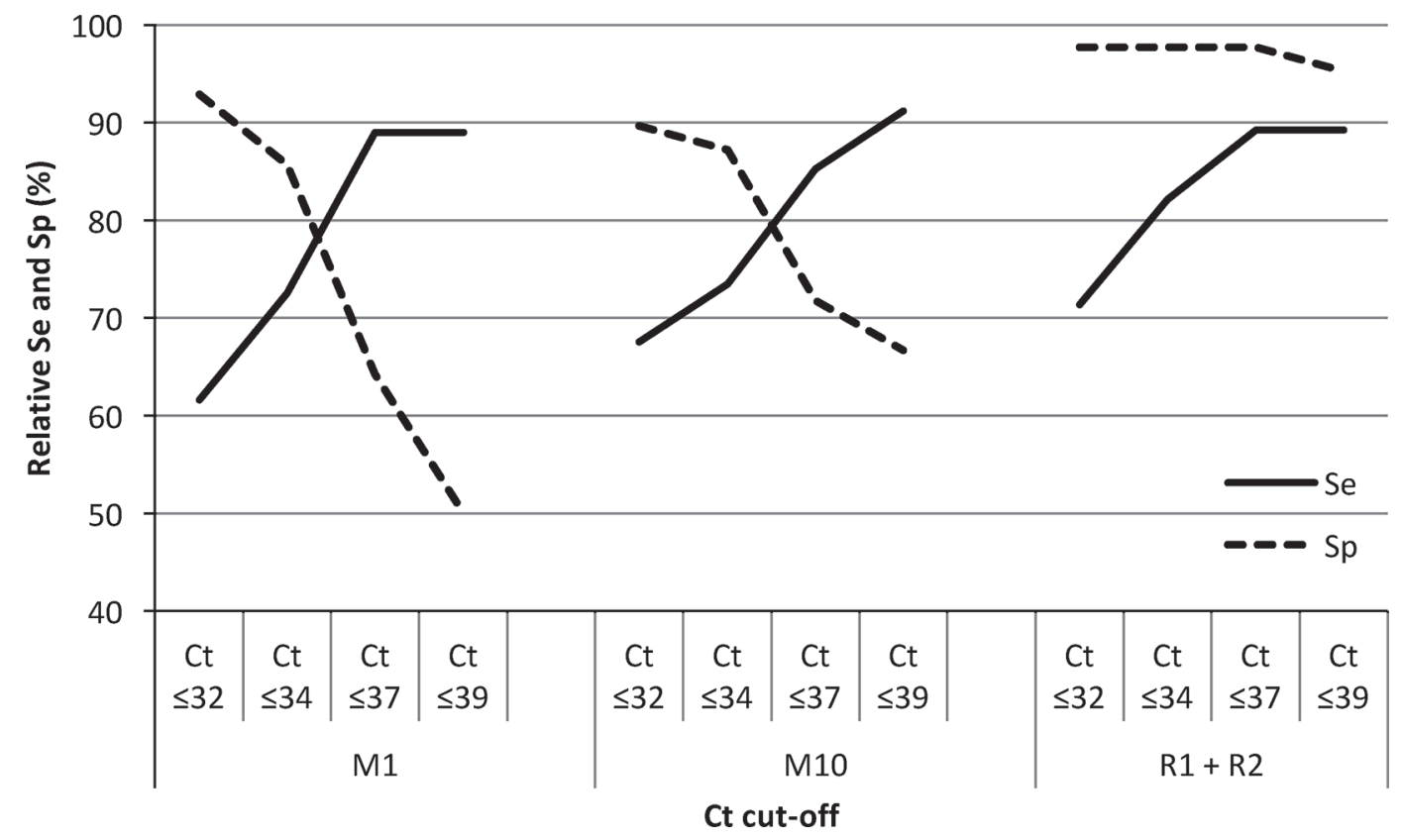

Figure 1. Relative sensitivity (Se) and specificity (Sp) of the PCR test using different PCR cycle threshold (Ct) cutoffs of $\leq 32, \leq 34, \leq 37$, and $\leq 39$ for identifying Streptococcus uberis in quarter milk samples collected at different sampling points: M1 = first milking; M10 = 10 th milking; $\mathrm{R} 1+\mathrm{R} 2$ = mid- and late-lactation combined. 
Table 4. Number, mean, SD, CV, and repeatability of PCR cycle threshold (Ct) values for sample duplicates with Ct values $<30$ or $\geq 30$ for the detection of Streptococcus uberis and Staphylococcus aureus in quarter milk samples

\begin{tabular}{lccccc}
\hline Item & Number & Mean & SD & CV $^{1}(\%)$ & Repeatability $^{2}$ \\
\hline Strep. uberis & 41 & 27.4 & 0.36 & 1.3 & 0.99 \\
$\mathrm{Ct}<30$ & 46 & 33.7 & 0.67 & 2.0 & 1.87 \\
$\mathrm{Ct} \geq 30$ & 13 & 28.4 & 0.28 & 1.0 & 0.80 \\
Staph. aureus & 14 & 32.4 & 0.70 & 2.2 & 1.97 \\
$\mathrm{Ct}<30$ & & & & \\
$\mathrm{Ct} \geq 30$ & &
\end{tabular}

${ }^{1} \mathrm{SD}$ divided by the mean.

${ }^{2} \mathrm{SD}$ multiplied by 2.8

\section{DISCUSSION}

The validation study for the PathoProof PCR assay confirmed that Strep. uberis and Staph. aureus could be identified in milk collected fresh from individual quarters or stored frozen for a period. However, when the recommended protocol was followed, the PCR assay failed to detect DNA in 3 samples, all of which had abnormal consistency (e.g., colostrum or clots from clinical mastitis). Reaction failure was also observed in similar samples in the same laboratory, though not all samples with these characteristics were affected ( $R$. Thresher, unpublished data). Variable amounts of PCR inhibitors are present in milk collected from different cows and at different stages of lactation or infection status (Chakravorty and Tyagi, 2005; Botaro et al., 2013). Extraction of DNA should successfully remove inhibitors, such as calcium ions, proteinases, fats, and milk proteins, that block the DNA polymerase activity (Wilson, 1997). Dilution of the DNA extract in water can reduce PCR inhibition to some extent, but it may compromise sensitivity by reducing the concentration of bacterial DNA. A $\sim 3.3$-cycle shift upwards can be expected with a 1-in-10 dilution (Koskinen et al., 2009). Thus, samples with a $\mathrm{Ct}>34$ could become $\mathrm{Ct}$ $>37$, which would be considered negative according to the threshold set by the manufacturer. The inclusion of both undiluted and 1-in-10 diluted replicates for all colostrum and clinical samples in the test performance comparison maximized the ability to detect DNA.

Relative sensitivity and specificity for detecting Staph. aureus were high at 96.4 and $99.7 \%$, respectively. The dilution step improved the sensitivity from 92.9 to 96.4\%. Previously, the sensitivity of detecting Staph. aureus has been reported as $97 \%$ for milk samples sent to a diagnostic laboratory (Hiitiö et al., 2015) and $87 \%$ for clinical mastitis cases (Koskinen et al., 2010). Specificity ranged from 92 to $99 \%$ in comparisons of the PathoProof PCR assay with culture (Taponen et al., 2009; Koskinen et al., 2010; Hiitiö et al., 2015). Although this specificity appears high, the consequence of a false-positive Staph. aureus result is greater than that for Strep. uberis because the Staph. aureus cow may be culled. This study indicates that Staph. aureus detection by PCR is comparable with culture.

Relative sensitivity and specificity estimates were 86.8 and $87.7 \%$ for detecting Strep. uberis. Without the dilution step, Strep. uberis would not have been detected in 11 samples, reducing the overall test sensitivity to $79.2 \%$. The sensitivity of the PCR assay for Strep. uberis detection was lower (68\%) and specificity similar $(90 \%)$ in a large Finnish and Dutch study in which $94 \%$ of samples were from cows with clinical mastitis (Koskinen et al., 2010). Lower sensitivity may reflect inefficient DNA extraction because the DNA extraction method in that study used spin-columns, which have poorer performance with clotted milk samples (Cressier and Bissonnette, 2011). Although sensitivity was similar throughout lactation in this study (excluding D30 samples), the specificity of detecting Strep. uberis was lower for M1 (64\%) and M10 (72\%) than later in lactation $(98 \%)$. These estimates are similar to those in the only other known study using milk collected in early lactation (Azizoglu et al., 2011); however, no pathogenspecific measures were provided.

The PCR assay did not detect Strep. uberis in 19 culture-positive samples (6\%), 16 of which were from early lactation (M1, M10, or D30). Eleven of these falsenegative samples identified Strep. uberis at concentrations ranging from 100 to $3,600 \mathrm{cfu} / \mathrm{mL}$. Koskinen et al. (2008) reported that the PathoProof assay's detection limit in milk ranged from 200 to $810 \mathrm{cfu} / \mathrm{mL}$, but they did not provide pathogen-specific results. Inefficient DNA extraction provides a plausible explanation for the inability of the PCR assay to detect Strep. uberis DNA in these samples. The analytical sensitivity of the PathoProof PCR assay was reported at $100 \%$; however, the assay was designed in Finland and the Netherlands (Koskinen et al., 2009), so the protocol for extracting DNA may not be well suited to milk samples of different composition, such as colostrum or the higher fat content of milk produced by the cows used in this study. 
Development of the PathoProof PCR assay incorporated a range of isolates $(\mathrm{n}=29)$ from 6 countries in North America and Europe (Koskinen et al., 2009). Strains of Strep. uberis from other geographical regions were assumed to be sufficiently similar to be detected. In this study, 2 samples collected 1 wk apart in late lactation from the same quarter were Strep. uberis positive in culture at relatively high concentrations of 1,800 and $3,600 \mathrm{cfu} / \mathrm{mL}$, and confirmed by API Strep testing, but were not identified by PCR. Strain differences might explain these false-negative results, so this PCR kit may have limitations for some markets.

Bacterial culture was used as the reference test because it remains the current gold standard (Hogan et al., 1999). Culture has limitations as a reference test. If PCR correctly identified bacteria missed by culture, the PCR test specificity would be underestimated. In the test comparison, 21 samples $(6.7 \%)$ were negative in culture, but positive by PCR. In 13 of these apparent false positives, the preceding sample from the same quarter was Strep. uberis positive in both culture and PCR, possibly indicating that bacteria were present but not culturable, or that bacterial concentration was too low to be detected by culture (i.e., $<100 \mathrm{cfu} / \mathrm{mL}$ ). To maximize the ability to detect bacteria in culture, an enhanced gold standard was used consisting of (1) a lower threshold for defining a sample as positive [100 $\mathrm{cfu} / \mathrm{mL}$ compared with $300 \mathrm{cfu} / \mathrm{mL}$ as recommended by NMC (Hogan et al., 1999)], and (2) parallel interpretation (Dohoo et al., 2011a) of bacteriological tests (positive in fresh culture, frozen culture, or plate colony counting) for each individual sample. A lower threshold has been suggested as a means of identifying as many existing infections as possible (Dohoo et al., 2011b); however, 1 colony may not be sufficient to declare an infection, particularly for environmental pathogens. As an alternative to parallel interpretation, series interpretation (where all 3 of the bacteriological tests had to be positive to declare a quarter sample as positive) demonstrated only a slight increase and decrease in relative sensitivity (91.1\%) and specificity (82.3\%) estimates, respectively. Latent class analysis provides an alternative method for evaluating diagnostic tests when no perfect reference test is available (Dohoo et al., 2009). Although it has been used in PCR validation studies (Cederlöf et al., 2012; Paradis et al., 2012), latent class analysis was not appropriate here because the test sensitivity and specificity were not constant across subpopulations, therefore failing to meet one criterion required for this analysis (Enøe et al., 2000).

Collecting consecutive samples from individual quarters over time assisted interpretation of conflicting PCR and culture results. Three samples were PCR positive but culture negative at one sample point and were positive in both methods at the subsequent sample. The PCR might have detected the infection before culture, which may provide some advantage in terms of treatment and prognosis, depending on the pathogen. Nevertheless, microbiome studies have illustrated the potential for culture-independent methods to provide false-positive results with almost all samples tested, having detectable staphylococci and streptococci DNA even when the SCC was $<10,000$ cells $/ \mathrm{mL}$ (Oikonomou et al., 2012). The detection of a single DNA copy by PCR does not provide sufficient evidence to confirm a current infection (Hadgu et al., 2005) and may not constitute an indication for treatment (Hadgu, 1999). The same argument can be made for culture because the presence of low levels of bacteria can be attributed to contamination or teat surface colonization. Users of the test should consider additional cow and herdbased information such as inflammatory indicators and clinical mastitis history to support interpretation and decision making. Future improvements of PCR technology may allow for differentiation of DNA from live and dead bacteria, assisting in the interpretation of results.

The cutoff $\mathrm{Ct}$ value for the assay to determine positive and negative results was 37 , as defined by the manufacturer, but lower Ct cutoffs appeared to be more appropriate for early lactation samples. The variation between duplicates (CV) was larger for samples with $\mathrm{Ct}$ values $\geq 30$, compared with samples with $\mathrm{Ct}$ values $<30$, indicating more robust results when $\mathrm{Ct}$ values were lower (i.e., a higher bacterial load in the sample). A high Ct may be generated through cross-contamination, by nonspecific amplification of background DNA, or through the detection of nonviable bacteria (Burns and Valdivia, 2008). The risk of cross-contamination was minimized by changing the collection tubes for preparing samples for DNA extraction in the validation study. To reduce the likelihood of false positives, particularly in early lactation, a lower Ct cutoff, such as $\mathrm{Ct}<34$ could be applied, but a reduction in sensitivity would be expected (from 89 to $77 \%$ ). Based on these estimates, 30 to $40 \%$ of infections caused by Strep. uberis would have been missed with this lower Ct cutoff for M1 and M10 samples.

Most of the conflicting results between culture and the PathoProof PCR assay for detecting Strep. uberis occurred in samples collected in early lactation. The ability of the PCR assay to detect bacterial DNA in milk depends not only on the concentration of bacteria in the sample but on the condition of the sample, which may affect the efficiency of the DNA extraction. Despite the limitations of the gold standard used, our data suggest that this PCR assay is not a better alternative to culture for detecting Strep. uberis in milk in early lactation, although we observed near equivalent 
performance of PCR and conventional bacterial culture for detecting Staph. aureus.

\section{ACKNOWLEDGMENTS}

We thank the DairyNZ farm and technical staff for assistance with sample collection, Barbara KuhnSherlock for statistical advice, and Livestock Improvement Corporation for the use of laboratory facilities. Funding for this project was provided by the Ministry of Business, Innovation and Employment (MBIE) and by New Zealand dairy farmers through DairyNZ Inc. (Hamilton, New Zealand).

\section{REFERENCES}

ASTM International. 2014. Standard Practice for Use of the Terms Precision and Bias in ASTM Test Methods. ASTM, West Conshohocken, PA. https://doi.org/10.1520/E0177-14.

Azizoglu, R. O., R. Rodriguez, R. Lyman, D. Asion, and K. A. Anderson. 2011. Bovine mastitis detection by real-time polymerase chain reaction and standard microbiology in early lactation quarter samples. Pages 131-132 in Proc. National Mastitis Council Annual Meeting. National Mastitis Council, Madison, WI.

Barkema, H. W., M. J. Green, A. J. Bradley, and R. N. Zadoks. 2009. Invited review: The role of contagious disease in udder health. J. Dairy Sci. 92:4717-4729.

Botaro, B. G., C. S. Cortinhas, L. V. Março, J. F. Moreno, L. F. Silva, N. R. Benites, and M. V. Santos. 2013. Detection and enumeration of Staphylococcus aureus from bovine milk samples by real-time polymerase chain reaction. J. Dairy Sci. 96:6955-6964.

Burns, M., and H. Valdivia. 2008. Modelling the limit of detection in real-time quantitative PCR. Eur. Food Res. Technol. 226:15131524.

Cederlöf, S. E., N. Toft, B. Aalbaek, and I. C. Klaas. 2012. Latent class analysis of the diagnostic characteristics of PCR and conventional bacteriological culture in diagnosing intramammary infections caused by Staphylococcus aureus in dairy cows at dry off. Acta Vet. Scand. 54:65.

Chakravorty, S., and J. S. Tyagi. 2005. Novel multipurpose methodology for detection of mycobacteria in pulmonary and extrapulmonary specimens by smear microscopy, culture, and PCR. J. Clin. Microbiol. 43:2697-2702.

Cohen, J. 1960. A coefficient of agreement for nominal scales. Educ. Psychol. Meas. 20:37-46.

Compton, C. W. R., C. Heuer, K. Parker, and S. McDougall. 2007. Epidemiology of mastitis in pasture-grazed peripartum dairy heifers and its effects on productivity. J. Dairy Sci. 90:4157-4170.

Cremonesi, P., B. Castiglioni, G. Malferrari, I. Biunno, C. Vimercati, P. Moroni, S. Morandi, and M. Luzzana. 2006. Technical note: Improved method for rapid DNA extraction of mastitis pathogens directly from milk. J. Dairy Sci. 89:163-169.

Cressier, B., and N. Bissonnette. 2011. Assessment of an extraction protocol to detect the major mastitis-causing pathogens in bovine milk. J. Dairy Sci. 94:2171-2184.

Dohoo, I., S. Andersen, R. Dingwell, K. Hand, D. Kelton, K. Leslie, Y. Schukken, and S. Godden. 2011a. Diagnosing intramammary infections: Comparison of multiple versus single quarter milk samples for the identification of intramammary infections in lactating dairy cows. J. Dairy Sci. 94:5515-5522.

Dohoo, I. R., J. Smith, S. Andersen, D. F. Kelton, and S. Godden., and Mastitis Research Workers' Conference. 2011b. Diagnosing intramammary infections: Evaluation of definitions based on a single milk sample. J. Dairy Sci. 94:250-261.
Dohoo, I. R., S. W. Martin, and H. Stryhn. 2009. Veterinary Epidemiological Research. 2nd ed. Ver Inc, Charlottetown, Prince Edward Island, Canada.

Enøe, C., M. P. Georgiadis, and W. O. Johnson. 2000. Estimation of sensitivity and specificity of diagnostic tests and disease prevalence when the true disease state is unknown. Prev. Vet. Med. 45:61-81.

Gillespie, B. E., and S. P. Oliver. 2005. Simultaneous detection of mastitis pathogens, Staphylococcus aureus, Streptococcus uberis, and Streptococcus agalactiae by multiplex real-time polymerase chain reaction. J. Dairy Sci. 88:3510-3518.

Hadgu, A. 1999. Discrepant analysis: A biased and an unscientific method for estimating test sensitivity and specificity. J. Clin. Epidemiol. 52:1231-1237.

Hadgu, A., N. Dendukuri, and J. Hilden. 2005. Evaluation of nucleic acid amplification tests in the absence of a perfect gold-standard test: A review of the statistical and epidemiologic issues. Epidemiology 16:604-612.

Hiitiö, H., R. Riva, T. Autio, T. Pohjanvirta, J. Holopainen, S. Pyörälä, and S. Pelkonen. 2015. Performance of a real-time PCR assay in routine bovine mastitis diagnostics compared with indepth conventional culture. J. Dairy Res. 82:200-208.

Hogan, J., R. Gonzales, R. Harmon, S. Nickerson, S. Oliver, J. Pankey, and K. Smith. 1999. Laboratory Handbook on Bovine Mastitis. National Mastitis Council, Madison, WI.

Koivula, M., A. Pitkälä, S. Pyörälä, and E. A. Mäntysaari. 2007. Distribution of bacteria and seasonal and regional effects in a new database for mastitis pathogens in Finland. Acta Vet. Scand. $57: 89-96$.

Koskinen, M. T., J. Holopainen, S. Pyörälä, P. Bredbacka, A. Pitkälä, H. W. Barkema, R. Bexiga, J. Roberson, L. Sølverød, and R. Piccinini. 2009. Analytical specificity and sensitivity of a real-time polymerase chain reaction assay for identification of bovine mastitis pathogens. J. Dairy Sci. 92:952-959.

Koskinen, M., J. Holopainen, L. Salmikivi, H. Lehmusto, S. Niskala, and J. Kurkela. 2008. Analytic detection limit of the PathoProof ${ }^{\mathrm{TN}}$ Mastitis PCR assay determined using two different experimental approaches. Pages 183-189 in Proc. Mastitis Control-From Science to Practice. Wageningen Academic Publishers, Wageningen, the Netherlands.

Koskinen, M. T., G. J. Wellenberg, O. C. Sampimon, J. Holopainen, A. Rothkamp, L. Salmikivi, W. A. van Haeringen, T. J. Lam, and S. Pyörälä. 2010. Field comparison of real-time polymerase chain reaction and bacterial culture for identification of bovine mastitis bacteria. J. Dairy Sci. 93:5707-5715.

Mahmmod, Y. S., N. Toft, J. Katholm, C. Grønbæk, and I. C. Klaas. 2013. Bayesian estimation of test characteristics of real-time PCR, bacteriological culture and California mastitis test for diagnosis of intramammary infections with Staphylococcus aureus in dairy cattle at routine milk recordings. Prev. Vet. Med. 112:309-317.

Oikonomou, G., V. S. Machado, C. Santisteban, Y. H. Schukken, and R. C. Bicalho. 2012. Microbial diversity of bovine mastitic milk as described by pyrosequencing of metagenomic $16 \mathrm{~s}$ rDNA. PLoS One 7:e47671.

Paradis, M.-È., D. Haine, B. Gillespie, S. Oliver, S. Messier, J. Comeau, and D. Scholl. 2012. Bayesian estimation of the diagnostic accuracy of a multiplex real-time PCR assay and bacteriological culture for 4 common bovine intramammary pathogens. J. Dairy Sci. 95:6436-6448.

Pol, M., and P. Ruegg. 2007. Treatment practices and quantification of antimicrobial drug usage in conventional and organic dairy farms in Wisconsin. J. Dairy Sci. 90:249-261.

Taponen, S., L. Salmikivi, H. Simojoki, M. Koskinen, and S. Pyörälä. 2009. Real-time polymerase chain reaction-based identification of bacteria in milk samples from bovine clinical mastitis with no growth in conventional culturing. J. Dairy Sci. 92:2610-2617.

Watts, J. L. 1988. Etiological agents of bovine mastitis. Vet. Microbiol. 16:41-66.

Wilson, I. G. 1997. Inhibition and facilitation of nucleic acid amplification. Appl. Environ. Microbiol. 63:3741-3751. 